\title{
Exploring the Necessity of Private Military Companies in the Fight against Insurgency in Nigeria
}

\author{
Miebaka Nabiebu${ }^{1}$, Eni Alobo ${ }^{2}$
}

\footnotetext{
${ }^{1}$ (LL.B; B.L; LL.M. Pgd; Strathclyde University, Scotland, UK), Industrial Relations/Management Consultant and Doctoral Candidate, Faculty of Law, University of Calabar-Nigeria; 2348184600000 mdlaw2004@yahoo.com

${ }^{2}$ Lecturer, Faculty of Law, University of Calabar-Nigeria; 2348036822222 aloboenie@yahoo.com
}

\begin{abstract}
The boko haram sect is waging an intractable insurgency war against the Nigeria state. This insurgency which started in 2009 has assumed a devastating dimension and seems to have overwhelmed the Nigerian armed forces. Although the current administration has consistently and regularly maintained that boko haram have been decimated and technically defeated the reality is that the sect is becoming deadlier and more daring by the day. Attacks are no longer limited to soft objects and civilians but targeted at the armed forces so as to gain military advantage. The recent sacking of a military battalion at Metele in which the army was completely and effectively annihilated by the sect bears eloquent testimony. It is therefore without equivocation that the Nigerian armed forces have no military capacity to contain and defeat boko haram. This position is further strengthened by the use of noncombatants called Civilian Joint Tasks Forceby the government. It is for these reasons that we are making a case for the use of Private Military Companies (PMCs) in the fight against boko haram. Since the 2003 war in Iraq, PMCs have become increasingly legitimate actors in modern conflicts. In fact, it is believed that the then Nigerian government surreptitiously deployed the use ofPMCs in effectively containing the boko haram in March 2015 thereby making it possible for elections to be held in the northeast of Nigeria. This article evaluates the boko haram insurgency from the view point of the failure of the Nigerian Armed Forces to curb the crises, the resort to the use of civilian joint task force and the necessity to deploy the use of PMCs as a solution to boko haram insurgency. The article concludes that PMCs have gained improved image in the world and had actually impacted positively on the Nigerian counterinsurgency effort within the short period it was deployed.
\end{abstract}

Keywords - Insurgency, Private military companies, Civilian Task Force, Boko Haram.

\section{INTRODUCTION}

Conflict is a scrimmage among persons or parties who aim at gaining certain objectives or advantages while concurrently neutralizing, injuring or if possible eliminating rivals' (Obaditan, 2003). For Ifediora (78), 'conflicts are quarrels, fights or struggles between interest groups and are one of the inescapable consequences of man's interaction with fellow humans and his environment.' In another understanding it is a 'struggle over values and claims to scarce status, power and resources in which the aims of the opponents are to neutralize, injure, or eliminate their rivals' (Coser, 1956). Conflict is not merely the outright hostilities, the firing guns and resounding battle cries. It is a constant strife that is being played out on a day-to-day basis which now and again erupts into its dramatic form of the opposing armies acting on the theatre of war. As communities and civilizations developed, so did conflict. As societies became more complex so did the nature of conflict. As conflict became more complex, so did the organization of those that engaged in them. Nigeria Nation has experienced several conflicts including a civil war that broke out on $6^{\text {th }}$ January, 1967. The war was the culmination of an uneasy peace and stability that had plagued the nation from independence in 1960. The immediate cause of the civil war itself may be identified as the coup and the counter coup of 1966 which altered the political equation and destroyed the fragile trust existing among the major ethnic groups. This regrettable civil war which ended in 1970 occasioned tremendous damage to the Nigerian state.

The insurgency Nigeria faces today appears to be deadlier and more voracious than the civil war. Since 2009, the violent activities of Boko Haram have caused major mayhem and uncertainty in Nigeria. The intensification of fierceness in 2013 climaxed with the declaration of a state of emergency in the north-eastern region of Nigeria. This declaration is in accordance to the provisions of section 305 
of the 1999 constitution of Nigeria which provides that the President may by instrument published in the Official Gazette of the Government of the Federation issue a Proclamation of a state of emergency in the Federation or any part thereof. Sub section 2 of section 305 mandates the President to immediately after the publication, transmit copies of the Official Gazette of the Government of the Federation containing the proclamation including the details of the emergency to the President of the Senate and the Speaker of the House of Representatives, each of whom shall forthwith convene or arrange for a meeting of the House of which he is President or Speaker, as the case may be, to consider the situation and decide whether or not to pass a resolution approving the Proclamation. It should be noted that the proclamation of a state of emergency is an extreme conflict resolution strategy adopted only when the Nigerian Federation is at war or when the Federation is in imminent danger of invasion or involvement in a state of war or there is actual breakdown of public order and public safety in the Federation or any part thereof to such extent as to require extraordinary measures to restore peace and security. Unfortunately and quite regrettably, this extraordinary step did not yield the desired result of curbing the insurgency.

Rather, Boko Haram continued to magnify, proclaiming a so-called caliphate in 2014 and commencing in the next year a pledge of loyalty and faithfulness to the Islamic State. Obviously, the reason behind the Boko Haram insurgency in Nigeria is strategically political, in that the insurgents are attempting to replace the Nigerian state with an Islamic state governed by Sharia law, especially in the northern Muslim dominated region. Sharia law is an Islamic law based on the Quran, which regulates both public and private conduct (Merriam-Webster, 2016). Boko Haram believes a strict Islamic state under Sharia law would address the problems of fraud, bad governance, and Western influence, which does not meet the desires of the Muslim population. Since its emergence, the insurgent group has employed all forms of guerrilla tactics and violence to unleash mayhem against the state and people in an attempt to replace the Nigerian institutions, which they perceived as corrupt and Western inclined. Boko Haram took advantage of the prevailing situation to mobilize support, and recruited fighters to carry out a revolutionary Jihadist movement against the Nigerian state (U.S Department of Justice, 2014).

Accordingly, Boko Haram has carried out violent, horrific and indiscriminate attacks on innocent civilians. As their attacks increase and the situation in Nigeria continues to deteriorate, with increasing numbers of victims, there is continued destruction of the social and economic infrastructure and disruption of education services. The conflict has spread and intensified as a result of a complex web of socio cultural, economic, ethno religions and subregional factors. It has evolved into what appears to be a non-international armed conflict between Boko Haram and Nigeria security forces in the states of Borno, Yobe and Adamawa and has been marked by egregious violations committed by both sides (Mohammed, 2014).

The Nigerian government has made several futile efforts in an attempt to confront the boko haram onslaught. The government deployed a Military Joint Task Force consisting of all the armed forces, paramilitary and police. This military strategy is still in existence and apparently has not achieved the expected result. The Nigerian state has however responded to the Boko Haram crisis with both a 'stick' and a 'carrot,' two approaches in an effort to solve the boko haram dilemma. The carrot tactic has involved an endeavour to engage Boko Haram members in political negotiations and/or dialogue. In April 2013, for example, former Nigerian President, Goodluck Jonathan, established a 26 member amnesty Committee on Dialogue and Peaceful Resolution of Security Challenges in the North, headed by the then Nigerian Special Duties Minister KabiruTanimu and comprised of government officials, religious authorities, and human rights activists. This committee had a three-month mandate to try to convince Boko Haram to surrender its arms in exchange for a state pardon and social integration. However, Boko Haram leader, Shekau, responded to the amnesty entreaties by saying that his group had done no wrong and that an amnesty would not be applicable to them, arguing that it was the Nigerian government committing the atrocities (Chiles, 2013).Thus, the government has also attempted the use of the same pacific methods it used to combat the Niger Delta militants to address the Boko Haram. Much within expectation, this strategy failed because the Boko Haram is with revolting ideologies, whose fundamental demands is capable of destabilizing the Nigeria state. The sect is devoid of any genuine or legitimate political or economic grievances that are capable of solution and resolution. Thus, in spite of the holistic military approach that has been adopted in curbing Boko Haram in Nigeria, the frequency and regularity of the incidences of terrorism and insurgency becomes higher and more complicated.

The boko haram insurgency has persisted for many reasons. First, the sect rides on the crest wave of religious motivation to recruit fighters and gain acceptance of the populace. Second, the sect seems to have easy access to arms. The proliferation, availability and the use of weapons of mass 
destruction to wit, explosives, biological, radiological and nuclear weapons have continued to energize and sustain the sect. Boko Haran appears to have unhindered support in form of manpower, material, fund, intelligence, arms and ammunitions at the domestic and International levels. By contrast, Nigerian soldiers, particularly in the northeast, reportedly suffer from low morale, struggling to keep pace with a sect that is increasingly well-armed and trained. By many accounts troops are not adequately resourced or equipped despite humongous security budget.Third, corruption cannot be insulated from this conflict. Corruption has eaten deep into the Nigerian society permeating all sectors of the economy. Resources budgeted for the military to fight insurgency are wantonly plundered with impunity and without consequence. As a result, the armed forces are left to fight without adequate arms, logistics, motivation and inspiration. Besides, unemployment is a potent force and circumstance for terrorist activities to spring up. This has become a grave problem in the country and has led to redundancy of our educated youths thereby eliciting frustration and encouraging involvement in activities that are injurious to the society. Closely related to this is the problem of poverty. The cruelsequence of poverty continues to devastate the Nigerian society to the extent that majority of the citizens cannot afford three square meals per day.Thus, among the various dynamics limiting the government's response to Boko Haram are a lack of coordination and cooperation between Nigerian security agencies; corruption; unemployment; poverty; misallocation of resources; limited requisite databases; the slow pace of the judicial system; and lack of sufficient training for prosecutors and judges to implement anti-terrorism laws.

The failure of the armed forces to contain the voracious and deadly activities of boko haram resulted in the appearance of a new vigilante group popularly known as the Civilian Joint Task Force CJTF. Originally, the (CJTF) members were a horde of shiftless, but infuriated young men, residing in different parts of the Northeast, who endured years of aggression on their population and disturbance of their lands by the boko haram insurgents. Exasperated, they decided to join the anti-terror war willingly to unshackle their populations from the deadlyhands of Boko Haram (Ibekwe, 2016). The CJTF acquired a measure of acceptance from the people and collaboration with the armed forces. This is because they are involved in piloting security checks, acting as informants to security agents on Boko Haram, and exposing Boko Haram's hideouts to the security forces. They also fight the insurgents on the battlefront side by side with the military, and carry out rescue missions to save those in captivity of Boko Haram (Ibekwe, 2016). The emergence of CJTF is an eloquent testimony that the Nigerian armed forces have been obviously overwhelmed by the boko haram insurgents and the people are taking the initiative to defend themselves.

A private military company (PMC) as the name implies is a private corporation providing fortified combat or security services for monetary advantage. The services and proficiency offered by PMCs are characteristically analogous to those of governmental security, military or police forces, most often on a specific and lesser scale. PMCs are usually involved in direct engagement of the enemy or command of regular troops. A typical example is afforded by the former South African Firm Executive Outcomes which functioned in Sierra Leone in 1995. The companypositioned an entire battalion to support the armed forces of Sierra Leone in their fight against rebel forces (Shearer 1998). While PMCs often provide services to train or supplement official armed forces in service of governments, they can also be employed by private companies to provide defenders for key staff or protection of company premises, especially in hostile territories as is the case in the Niger Delta Region of Nigeria where multinational oil firms operate. The abysmal failure of the Nigerian armed forces in the fight against the boko haram insurgents and the resort to CJTF which also expectedly failed leaves the Nigerian government with the inevitable option of engaging the services of a PMC to immediately exterminatethe boko haram insurgents.

This paper basically focuses on the failure of the Nigerian armed forces to contain the boko haram insurgency and the attempt to rely on the Civilian Joint Task Force (CJTF) as a way out of the crises. It examines the viciousness and seeming indomitability of the insurgents and makes a case for the immediate engagement of a PMC by the Nigerian government as potent solution to this intractable insurrection. The paper is evaluative and analytical in essence and uses qualitative research methodby generating relevant literatures from secondary sources of data such as the Internet, Newspapers, Journals, Books and other relevant literatures.

\section{BOKO HARAM REMAINS UNCONQUERAB LE}

Boko Haram has become notorious for its extreme violence. In 2014, the Global Terrorism Index designated it as the most deadly terrorist group in the world. The group has killed an estimated 15,000 people, kidnapped tens of thousands, displaced 2.3 million, and destroyed entire 
communities (Thurston, 2016).The perilous height the boko haram insurgency has attained is worrisome. Nigeria undoubtedly is faced with terrorism; a worldwide phenomenon where no one is safe (Adagba and Eme, 2012). The Nigeria state is gradually slipping into a disastrous state where lives and property of the citizenry are unprotected because of the deadly activities of boko haram. A cardinal responsibility of any government is the protection of lives and property and this is achieved through the control of the instruments of coercion. With regard to the Boko Haram and the menace of criminal generally in many part of the polity, the government has not been able to proffer any effective solution.

We do not intend to go into any historical retrospection of the deadly activities of the rampaging Boko Haram insurgents because we have recent examples of their havoc against the Nigerian state. The sect recently overran a Nigerian Army battalion in Borno State on Sunday, killing the unit's commander and dozens of soldiers. A large cache of arms, ammunition and military equipment were carted away by Boko Haram fighters during the attack on 157 Task Force Battalion in Metele, Abadam Local Government Area, at about 6:00 p.m. This attack is remarkable for many reasons. First, it was an attack against a military target designed to gain military advantage as against soft target attacks. Second, the entire military battalion was completely annihilated without any challenge and/or reinforcement from the military. Several soldiers from the battalion have already been confirmed killed, amongst them their commander. In fact, military sources were unable to tell the number of Boko Haram casualties (Ogundipe, 2018).

The enormity of destruction and carnage caused by that round of attacks by the sect were unparalleled by any other attack that had been carried out in the history of the sect. What has become obvious in the fight against insurgency in Nigeria is that the even though the Nigerian government has employed military approach in its attempt to defeat Boko Haram, the group has grown in membership and has adopted deadlier, more sophisticated tactics making it one of the most lethal of its kind in the world today. Boko Haram is now indisputably seen as part of a global terrorist network and the Nigerian government pursues a predominantly counterterrorism strategy focused on dynamic military operations designed to kill and capture its fighters. The Nigerian military has on occasion claimed to have succeeded in demolishing Boko Haram. However, despite an increased military presence in the northeast, the group has proven to be adaptive and highly resilient and the government has been unable to dismantle the group or protect the population from attacks and retaliatory raids (Matfess, 2016).

The Nigerian armed forces as it is presently composed do not have the capacity to win the insurgency war. An effective and result oriented counterinsurgency campaign and military operations that can dislodge Boko Haram must be accompany with political, economic, and progressive transformations. The Nigerian military writhes from various foundational weaknesses that have limited its success against Boko Haram. These challenges include lack of professionalism, low morale, inadequate training, lack of appropriate or usable equipment, poor coordination and cooperation between security agencies, corruption and misallocation of resources. According to a U.S. Department of Defense as sessment, Nigerian troops are "showing signs of real fear," and becoming "afraid to even engage." Frustration has reached such a level that soldiers in the Seventh Division recently opened fire on their commanding officer after twelve of their comrades were killed in an ambush. Matters are made worse by the government's ability to gather credible intelligence adequate enough in fighting a surreptitious group like Boko Haram. This situation has made it impossible to conduct effective operations or protect its forces in the field. The Nigerian army fighting the terrorists is currently under-equipped, illmotivated, cowardly and heavily compromised.

What is clear is that the Nigerian government is oblivious of sensitive information about the sect thereby making it difficult to plan a viable counterinsurgency strategy. From all indication, the government has no accurate approximation of the statistical strength of Boko Haram, its structural forms, and intelligence-gathering methods to enable the government to devise realistic strategies for confronting and containing the sect. By contrast, Boko Haram demonstrates adequate knowledge of government counterinsurgency strategy and uses such informed position to wreak havoc on Nigerian troops. The accuracy of their intelligence has raised concern of collusion between the sect and some members of the armed forces. The sect operates with high degree of precision, secrecy, speed and surprise leaving unquantifiable destruction. One fact that has become apparent is that the sect has shown an unbelievable ability for reorganizing after major setbacks. The truth is that terrorists, because of their perfidious and gorilla approaches, are not easily defeated by weak military.

Boko Haram onslaught against the military has increased in intensity and frequency and this is because of increased militarization manifested in the use of heavy weaponry, such as anti-aircraft guns, armoured vehicles, and conventionalized attacks on military targets. Some of the 
weapons were acquired through the vibrant arms trade in the area and possibly because of the increased availability of weapons following the 2011 destabilization of Libya (Higazi, 2015). However, most weapons were acquired from looting police stations and army bases, and from commandeering weapons from fleeing soldiers.

From the above, it is clear that the successes of Boko Haram have been made possible mainly by the unproductive counterinsurgency campaign of the Nigerian security forces. Nigeria has witnessed different forms of conflict ranging from sectarian to ethno-religious crises, whole sale abduction, hostage taking, arson, incidents of cattle rustlings and terrorism in the North. All these have had severe consequences on human and material resources of the nation and the armed forces seem to be overwhelmed. Boko haram has introduced a higher level of aggression and wanton destruction of lives and properties and this has exposed the weakness and inadequacy of the Nigerian military.

\section{THE USE OF CIVILIAN JOINT TASK FORCE}

It is not uncommon for civilians or group of citizens to rise up in challenge to armed invasion that is considered threats to the security of their community. Civilians saturate the modern battlefield, often engaging in activities that have traditionally been performed by members of the armed forces. Their rise usually emanates from the seeming inability of constituted authority to enforce law and order, or perceived delays in carrying out justice. The CJTF came into existence in June 2013 and is made up of mainly young male civilians who want to identify with and support the fight against boko haram. Their main objective is to ensure the arrest of Boko Haram insurgents. It should be noted that CJTF came into existence by an informal spontaneous reaction by civilians who were frustrated by the insecurity and devastation occasioned on their environment by the boko haram insurgents. Being civilians, the CJTF merely operated with bare hands, sticks, clubs, stones, etc. Over time, they came to acquire locally made guns to aid themselves in manning checkpoints and repelling onslaught. The emergence of CJTF is much within expectations. The boko haram insurgents operated without limitations causing grave destruction to the civilian population. Their attacks do not distinguish civilians from military objects. They adopted means and methods that occasion superfluous damage. This situation together with the apparent inability of the armed forces to contain the insurgents made the emergence of CJTF imminent and inevitable. Thus the issue of turning the gun against the citizen was what triggered the emergence of the CJTF. The risk that the youth faced gingered them to take steps for selfpreservation. By rising up opening against the insurgents, the CJTF is able to insulate herself from the suspicion of conspiracy and collaboration with the insurgents thereby preventing military intimidation, arrest and brutality. So the youths decided to organize to escape the onslaught of Boko Haram terrorists and harassment of military officers after every incident of attack. It was a significant development that helped in defining the relationship between the military and the civilian population.

It is pertinent to observe that the CJTF members have played many roles, from mostly discrete surveillance networks in the north-eastern region of Nigeria to military combat auxiliaries or semi-autonomous fighting forces in the country. These youths have used local skills to fish out hiding Boko Haram members in their various neighbourhoods. In the process, they have greatly helped in the improving civil-military relations(Afeikhena, 2015). On many occasions, CJTF has been useful in spotting Boko Haram insurgents, repelling attacks, and liberating towns and villages captured by Boko Haram.

Agbiboa, (2015) in his work the 'Youth as Tactical Agents of Peace building and Development in the Sahel' observed that:

An overlooked but critical area of the ongoing Boko Haram insurgency is the manner in which the angry youth in Northern Nigeria are contributing their quota as the conflict unfolds. To complement the efforts of the state's joint task force/multinational task force in the anti-terrorism war, they enlist against the insurgents with bows and arrows, swords and machetes in their communities thereby given combat and intelligence support respectively.

There is no doubt that the CJTF has contributed and is still contributing tremendously in the fight against boko haram insurgents but there are some legal concerns on their direct participation in the conflict. First, it should be noted that members of CJTF are not members of the Nigerian armed forces and therefore cannot legally be called combatants. That being the case, they are not supposed to be engaged in direct battle with the insurgents. Also, the CJTF are not participants in a levee en masse and therefore are not expected to participate directly in hostilities.

It should be noted that civilians who get involved in hostilities loss all the protection available under international humanitarian law. In particular, civilians 
taking a direct part maybe attacked, do not factor into proportionality calculations, and need not be considered when trying to minimize harm to civilians. This customary IHL rule is set forth for States parties in Article 51(3) of the 1977 Additional Protocol I to the 1949 Geneva Conventions for international armed conflict and Article 13(3) of Additional Protocol II for non-international armed conflict. Thus, International humanitarian law generally precludes the direct participation of civilians in armed conflict.

See, for example, the Report of the Inter-American Commission on Human Rights in which notes:

When civilians, such as those who attacked the Tablada base, assume the role of combatants by directly taking part in fighting, whether singly or as a member of a group, they thereby become legitimate military targets. As such, they are subject to direct individualized attack to the same extent as combatants. Thus, by virtue of their hostile acts, the Tablada attackers lost the benefits of the above mentioned precautions in attack and against the effects of indiscriminate or disproportionate attacks pertaining to peaceable civilians.

Members of the armed forces are taught the basic principles of international humanitarian law and are under strict obligation to abide and apply the rules in armed conflict situation. The CJTF members are basically illiterates who are unmindful of the rules of armed conflict. Expectedly, CJTF has been accused of human rights abuses and participation in extrajudicial killings. For instance, video footage published by Amnesty International of a gruesome attack alleged to have taken place on March, 14, 2014, shows what appear to be members of the Nigerian military and CJTF using a knife to slit the throats of a series of detainees before dumping them into an open mass grave.The CJTF has also been accused of raping women, false arrests, imprisonment, and arson. For example, reports from IDP camps allege the CJTF forcefully coerced females to have sex with them in return for food and protection(Caitriona and Drury, 2017). The situation is compounded by the absence of direct Government control over the vigilante group which has apparently given them the privilege to take the law into their hands by getting involved in various acts of human rights abuses, including harassment, extortion and extra-judicial killing of suspected insurgents in their neighbourhood.
Human rights abuses by the CJTF has become so endemic that on 13 July 2013, the Nigeria-based Human Rights Monitor (HRM) raised the alarm over the illegal activities of these youths who were alleged to have set ablaze the house of the Chairman of the defunct All Nigeria People's Party (ANPP) in Borno state, Alhaji Othman, for his alleged closeness to some members of the Boko Haram sect (Mamah, 2013). According to HRM, the youth vigilante group have maimed and killed many people suspected to be members or financiers of Boko Haram insurgents in Borno and Yobe states (Mamah, 2013).

The extreme abuse of human rights by CJTF is regrettable and should be condemned. Human rights are those universally recognised values and freedoms, and the legal guarantees that safeguard individuals and groups against the actions and inactions of the State, agents of the State or other individuals that interfere with their natural entitlements and human dignity (Odomovo, 2014). As universally recognised values, the protection of human rights and fundamental freedoms are usually included as essential provisions of international law, especially human rights law and international humanitarian law, and these are reflected in major international human rights treaties notably, the Universal Declaration of Human Rights (UN, 1949). Because of their primacy, human rights and international humanitarian law should be guaranteed, promoted and protected in any situation but this is not the case in the current fight against insurgency in Nigeria.

It is imperative to observe that human rights law and international humanitarian law require States to promote and protect human rights and fundamental freedoms while countering insurgency (UN, 2013). Any counter-insurgency or counter-terrorism strategy adopted by States must therefore comply with the provisions of international human rights law and humanitarian law. Counter-terrorism and counter-insurgency differs in certain aspect, but they generally include any step taken to disrupt, dismantle and ultimately, defeat insurgents and terrorist organisations (Rineheart, 2010). It is the right and duty of every State to take effective counter-insurgency measures to ensure public security.Human rights law and International humanitarian law oblige States to be accountable for human rights violations committed by their security forces while combating insurgency and terrorism. In this regard, a global counter-terrorism strategy was adopted by the United Nations' General Assembly in Resolution 60/288 of 2006, in which certain steps were taken to ensure that all counterterrorism and counter- insurgency measures complies with international humanitarian law (Odomovo, 2014). 
Security forces in Nigeria are apparently out of control in the fight against insurgency and terrorism hence the resort to the use of CJTF. To date, one of the biggest obstacles to effective counter- insurgency operations in Nigeria is the lack of trust and cooperation from local communities. Regrettably, the acrimonious relationship between host communities and security forces makes it difficult to gather important security intelligence in support of government counter-insurgency efforts, and consequently makes it easy for insurgents to win the support and sympathy of local communities that dislike JTF tactics. Indeed, the current military offensive of JTFs is counter-productive. Beyond the display of lack of capacity to combat the threat of insurgency, the State through the instrumentality of the military and other security forces have, on several occasions, arbitrarily killed many civilians and destroyed entire communities (Wisdom, 2013). That being the case and in view of the numerous concerns raised above concerning the CJTF, it now necessary to look beyond the Nigerian armed forces and engage the services of PMCs to flush out and annihilate the boko haram insurgents.

\section{IV.}

\subsection{Private Military Companies in Armed Conflict}

PMCs are defined by Carlos Ortiz (2010), in 'Private Armed Forces and Global Security: A Guide to the Issues' as:

Legally established international firms offering services that involve the potential to exercise force in a systematic way and by military or paramilitary means, as well as the enhancement, the transfer, the facilitation, the deterrence, or the defusing of this potential, or the knowledge required to implement it, to clients.

For this research all roles were encompassed under the term PMCs including provision of convoy escort teams, protective security details, close protection, static security, mine and ordnance clearance, police and military mentoring, intelligence and language support. PMCs are generally identified as those commercial entities that provide both security and a military expertise to their clients. Ortiz (2007) considers that the PMC spectrum stretches from firms that offer the management of violence of the state, to those that restrict their activities to specific areas or tasks.

In the pastepochs, PMCs have played serious characters in armed military and security services. They have become very prevalent and relish great patronage from governments around the world. Private military actors have now challenged the monopoly of organised violence enjoyed by States since the Peace Treaties of Westphalia in 1648. They thrive and make huge profits from assorted types of military and security contracts. P. W. Singer describes PMC as "business Organization that trade in professional services intricately linked to warfare. They are corporate bodies that specialize in the provision of military skills, including combat operations, strategic planning, intelligence, risk assessment, operational support, training and technical skills (Singer, 2003). The general preference for PMCs which gathered momentum in the 1990s is attributed to a number of factors. The end of the Cold War around this period led to the downsizing of the armed forces of the major powers and the emergence of PMCs (Evgeni, 2015). Part of the traditional responsibilities hitherto vested in the regular State forces was contracted out to PMCs (Chukwuma and Ubong, 2014). Their customers include governments, corporate organizations, NGOs and rebel movements, among others. Thus, the State no longer enjoys monopoly in the provision of military and security services. Since the early 1990s, state and non-state actors trying to protect people and assets from military threats within different conflict environments have become increasingly willing to turn to PMCs for military services (Mandel, 2001). PMCs are involved in direct engagement of the enemy or command of regular troops, guarding support, military consultancy support and training, and logistical support. PMCs have the ability to significantly alter the strategic military landscape of a conflict, whether in a combative or non-combative role, often as a national defence force would (O'Brien, 2000).Furthermore they have played a decisive role in several conflicts, their presence sometimes determining the outcome of the conflict. PMCs have carried out operations from as far afield as Angola to Colombia and Papua New Guinea to Afghanistan. They have operated on every continent except Antarctica. The rise of PMCs is not a recent event (Singer, 2007). However, in the post-Cold War years, the private military industry has become an accepted alternative. Never before have PMCs been so well organised, equipped and able to "operate along business lines across the spectrum of conflict (Smith, 2003).

The utility and plausibility of PMCs is not farfetched. Most PMCs have superlative force structure consisting of adequate numbers, size, and composition of the units that comprise thedefense forces; e.g., divisions, ships, air wings. PMCs maintain technical sophistication of forces, units, weapon systems, and equipment and have the ability to 
provide capabilities required by the combatant commanders to execute their assigned missions. For instance, EO had military equipment and personnel at its exclusive disposal. EO had armoured personnel carriers with $30 \mathrm{~mm}$ cannons, amphibious armoured personnel carriers with mounted $7.62 \mathrm{~mm}$ machine guns, Land Rovers with anti-aircraft guns, artillery, electronic intercepting systems, Soviet Mi-24 gunships (helicopter), and Soviet Mi-17 helicopters armed with rocket pods (Isenberg 1997: 8). Moreover, EO had its own air force which contained two Boeing 727 supply planes, two Andover transport planes, Soviet MiG-23 jet fighter-bombers, Swiss Pilatus planes with air-to-surface missiles, and Soviet Mi-8 helicopters (Avant, 2005). As the Serbs, Croatians, Sierra Leoneans (particularly the RUF), and Angolans all learned, the involvement of PMCs in combat or non-combat roles can shift the balance of the conflict with the right conditions (Francis, 1999). The sustainability of their operations is guaranteed with the ability to maintain the necessary level and duration of operational activity to achieve military objectives. Sustainability is a function of providing for and maintaining those levels of ready forces, materiel, and consumables necessary to support military effort.

Moreover, the cost of maintaining a permanent military force with associated accommodation, medical and schooling costs presents a capitation cost well above the salaries paid to the individuals. Such additional factors are not required for PMCs where a set price is paid for the contracted service.A prominent example always bandied to underscore efficiency and cost is the clinical role of the EO which was hired by the Strasser government in March 1995 for $\$ 36$ million to flush out rebels of the Revolutionary United Front (RUF) from Freetown, Sierra Leone (Laura Dickinson, 2010). The use of PMCs can be funded on a short-term basis removing the need for major redundancy programmes for military personnel with their associated political ramifications as certain constituencies are affected. For weaker states it is possibly a means to secure their position and enhance internal, as well as external, security (Kramer, 2007).

\subsection{The Operation of Private Military Companies in Africa}

The continent of Africa has been torn apart by civil wars and ethnic strife after the Europeans imperialist powers bade goodbye to the region. Such an insecure and unfavorable environment produces weak state structures and unstable regimes. These conflicts have often been christened "new wars" as they ceased to rage between high Tech armies of states but between clan and ethnic leanings.
Consequently, such conflicts involve various parties to whom weapons of warfare became available in the global arms market. PMCs took advantage of this status quo and began rendering their services to the diverse groups in the region which heightened conflicts. A ready example can be seen in Angola where the Executive Outcomes, a PMC was contracted for $\$ 40$ Million to as sist the Angola government to retrain her armed forces and to supply ammunitions. Thus, it carried out an essential role, as due to its activities, a peace pact was reached even though the country slipped back into conflict when the company left. The following year, the Sierra Leonean government engaged this security outfit to offer protection to mining and mineral sites and to equally render assistance to the government in power.

In 1991, fighting started between the government of Sierra Leone and the Revolutionary United Front (RUF), a group of rebels backed by Liberia's Charles Taylor. By April 1995, the RUF had built up support and was amassing troops outside Freetown, the capital (Rita Nimka, 2009). The government's attempts to bolster the military had failed. Government troops lacked training and resources: they used child soldiers and provided rations in the form of marijuana and rum. EO was paid \$35million to re-establish government control over the country. Within nine days, the EO force stopped the rebel advance and sent them back 126 kilometers. They soon cleared the diamond fields and captured the RUF stronghold in Kangari Hills. The EO intervention stabilized the country and permitted democratic elections.

The winner of the elections, Ahmed Kabbah, chose to discontinue the use of EO's services, since the UN had promised to deploy troops and an ECOMOG force was present. EO warned that their premature departure would destabilize the country, and predicted that a coup would occur within 100 days after their departure. The UN troops were never deployed, and despite the presence of ECOWAS Monitoring Group (ECOMOG) troops, a coup did occur on the 95th day after the company's departure, and chaos resulted.

What could have been the reasons for the success of EO in the face of the stiff resistance from RUF in Sierra Leone? Fortna argues that the success can be described in terms of the contract, the skills of the company, and the situation itself (Fortna, 2009). She summarise these factors succinctly in the following words:

The success can be described in terms of the contract, the skills of the company, and the situation itself. EO had a timelimited contract to provide, not a general service, but specific outcomes. It was 
given unified command over the mission. Its troops were also composed of highly trained members of the South African Defense Force's 32nd Battalion, a Special Forces battalion consisting of soldiers from South Africa, Namibia, and Angola. They were knowledgeable not only in tactics but also in the conduct of war. Sierra Leone itself did not have a functioning military, so there was no possibility of conflict between two militaries fighting for the same party. In addition, Sierra Leone paid for the EO intervention out of the military budget.

It is submitted that the main reason why the Government of Sierra Leone terminated the engagement of the EO despite the successes recorded within a short time is not unconnected to legitimacy issues as they were involved in activities meant for the military even though the military was ill equipped at that time.

In Somalia, for more than two decades Somalia has been haunted by civil war, becoming a byword for perpetual violence. Suffering from the absence of a permanent and effective government, the country is regularly ranked as one of the most unstable areas in the world, and is found on the top of the list of failed states year after year. The turmoil in Somalia has offered lucrative investment opportunities for PMCs. PMCs acted in support roles for western armies in a series of international interventions in Somalia during the first half of the 1990s, after the fall of the regime in 1991. The current United Nations (UN) approved intervention, the African Union Mission in Somalia (AMISOM), also has PMSCs working under its umbrella. All three political entities within Somalia, namely Puntland, Somaliland and the Transitional Federal Government (TFG) in Mogadishu, have contracted PMSCs to build the capacities of their maritime security sector.

\section{THE NIGERIAN EXPERIENCE AND THE NEED TO DEPLOY PMCS}

Boko Haram's mobile insurgency warfare utilizing hit-andrun strategies and the ability to hide in the vast forest areas of Northeast Nigeria has rendered the responses of the highly conventional Nigerian army ineffective (Loke, 2016). A lack of intelligence, widespread corruption in the military, lack of payments and lack of professional skills have all contributed to the inept response of the security forces (Solomon, 2012). Moreover the military's tactic of conventional attrition warfare has been, and in general is, largely incapable of suppressing insurgency groups
(Oyewole, 2013). This has also been stressed by military spokesman, Maj. Gen Chris Olukolade (Aryn Baker, 2015).

Faced with this precarious situation and the unending devastation of lives and property by book haram, the former Nigerian president, Goodluck Jonathan, whose popularity was sharply decreasing because of Boko Haram especially the Chibok-girls kidnapping and the Baga massacre, and who had an upcoming election, hiredSpecialised Task, Training, Equipment and Protection (STTEP)(Falola and Heaton, 2014). In addition the hiring of STTEP coincides with the ending of US advisers mission to assist in locating the Chibok-girls (Blanchard,2014).

STTEP was contracted for three months to assist the Nigerian military in establishing a counter insurgency strike force, more precisely the 72 Mobile Strike Force (Jack, nd.). STTEP consist of members from former Apartheid military branches such as the South African Defense Force (SADF), the 32-Batalion and the Koevet unit with which Lotz had served. STTEP itself is chaired by the founder of the highly controversial security company Executive Outcomes (EO), Eeben Barlow.His men were incorporated into the Nigerian army, where Barlow himself was appointed the rank of major general. That STTEP soldiers also engaged in fighting is not denied by Barlow: "if you want someone to go to war for you, you need to be willing to show the way". This, he claims, was one of the central problems of the Nigerian command: they sit in offices far removed from the actual operations, detaching them from the realities of the field, and causing low morale among the troops.

STTEP brought a group of highly skilled, trained and experienced soldiers, who have conducted counterinsurgency warfare on the African continent since the 1980s. In addition, the soldiers received proper payment as well as benefits, and STTEP supplied an air capacity capable of transporting, evacuating and supplying troops, and conducting air-to-ground combat support. This boosts troop morale and enhanced the units fighting capacity (Justin Leach, 2016). STTEP moreover contributed with a solid counterinsurgency doctrine called relentless pursuit (also utilized by EO), which consist of confusing, dispersing, and putting pressure on the enemy through small mobile attacks, forcing it to withdraw, and then relentlessly pursuing the enemy thus exhausting it and facilitating its annihilation.

STTEP's contract was terminated, perhaps because of the June 2015 election, which ushered in a new security agenda for the country. This was the bane of the success of STEPP as they had limited time to combat the Boko Haram terrorist in the Northern region of Nigeria. The criticisms advanced against STEPP is not farfetched from the ones raised against 
$\mathrm{EO}$ as they are often times than not seen as undermining the sovereignty of a country and perpetuating violence as it were.

It should be noted that the intervention of PMCs in Nigeria is not entirely novel and is not limited to the Boko Haram insurgency in the Northern region of Nigeria. The Niger Delta region has gotten its own fair share in this regard. However, the interventions in this region are often orchestrated by the multinational Oil and Gas companies that have their area of operations sited there. One example is the entering into a security contract between Group4Securicor with Chevron Nigeria Ltd. Group4Securicor, through its subsidiary Outsourcing Services Ltd., in October 2002 was initially contracted to provide guards for Chevron's headquarters in Lagos, the two logistical bases in Port Harcourt and Warri, and the operational site in Escravos. Since then Outsourcing's contract with Chevron has expanded beyond traditional security guarding. Outsourcing Services Ltd.'s operations are integrated in a complex assemblage with the public security forces. Private security law in Nigeria prohibits PMSCs from carrying firearms. Nonetheless, because of the high level of crime, Group4Securicor finds it crucial to offer armed protection to its clients. PMSCs in the Niger Delta are important in securing the operations of the oil and gas companies; hence, the federal government can also rely on the oil income.

\section{CONCLUSION AND RECOMMENDATIONS}

PMCs engage in offensive military combat operations that are intended to alter the strategic landscape of a conflict or warfare. Combat Offensive PMCs focus on the tactical environment, offering services at the forefront of combat operations and capabilities, engaging in actual fighting or direct control and command of military units, clandestine warfare, basic and advanced battle handling, and sniper operations. Combat Offensive PMCs are able to deploy a military force in an attempt to help their clients maintain or restore political order, military power, or to change the strategic impact of a war. The successes recorded by the PMCs within the short period of their intervention in the Boko Haram insurgency created a congenial environment for elections to hold in the war ravaged north eastern Nigeria and there is no doubt that had their operations continued, boko haram would have been defeated.

The insurgents have exhibited superior knowledge in their understanding of terrain, and use of information to outsmart security forces on numerous occasions. They employ services of local inhabitants, who provide them with accurate intelligence about government forces. The group also enjoys the support of sympathizers, who are not necessary taking part in the struggle, but provide information for the insurgents because they have had lost faith in the government (Sadau, 2011).The Nigerian government in addressing the current defence and security challenge should do an overall strategic assessment of the character and scale of the threats and seek to provide capabilities that can, as closely as possible, address the problem. Since the effectiveness and utility of the Nigerian military's capabilities are inadequate to the threats it faces and the operational environment in which it operates, it is suggested that the Nigerian government should as a matter of military and security expediency engage the services of a PMC to flush out the boko haram insurgents.The Boko Haram insurgency presents a very intricate and precarious conflict which the Nigerian armed force is not trained to confront. The Nigerian army is proficient in conventional warfare and peacekeeping operations and is lacking in the area of counter-terrorism and counter-insurgency operations.

Even the U.S. departments are now dependent on PMCs in their day-to-day operation, from front line logistics to conducting security operations. The general assumption is that PMCs provide services that are competitive, cheaper, and more efficient than government agencies. One advantage that the private sector brings to public wars is capacity. Companies like Kellogg and Brown \& Root (KBR), claim that they are capable of supporting the deployment of 50,000 troops anywhere in the world on a short notice (James, 2008).The Nigerian government should therefore leverage on the capacity and potency of PMC by engaging their services to solve the boko haram revolt.

It is suggested that while the military option is being exercised to defeat Boko Haram, the derivation reasons of its occurrence should be addressed by the government. As noted earlier, the Boko Haram insurgency is rooted in the failure of government to provide solution to the problems of underdevelopment, illiteracy, unemployment, poverty, nepotism, tribalism and corruption. All these problems are currently systemic in Nigeria and have helped to fuel and intensify the conflict.Boko Haram is therefore a direct result of failure of governance and the breakdown of core social values in Nigeria.

\section{REFERENCES}

[1] Abubakar A. (n.d.). "Nigerian Civil War, Causes, Strategies, And Lessons Learnt". Available [online] at: http//www.africamasterweb.com/biafrawarcauses.html. Accessed on 15 Jan., 2011 
[2] Adagba, U. \&Chijioke O. (2012). Activities of Boko Haram and Insecurity Question in Nigeria.Arabian Journal ofBusiness andManagement Review, Vol. 1, No. 9.

[3] Afeikhena, J. (2015). "Lessons from Colombia For Curtailing The Boko Haram Insurgency In Nigeria," PRISM 5:2 (2015): p. 100.

[4] Agbiboa, D. (2015). Resistance to boko haram: civilian joint task forces in North-eastern Nigeria. Conflict Studies Quarterly Special Is sue.

[5] Aghedo, I. and Osumah, O. (2012) "The Boko Haram Uprising: How Should Nigeria Respond?" Third World Quaterly, 854.

[6] Ales, W. and Rachel I. (2013). "Hybrid Social Movements in Africa," Journal of Contemporary African Studies, p. 310.

[7] Amnesty International, (2009). 'Killing at Will: Extrajudicial Executions and other Unlawful Killings by Police in Nigeria', Available [online] at: https://www.amnesty.org/en/library/asset/

AFR44/038/2009/en/f09b1c15- 77b4-40aa-a608b3b01bde0fc5/afr440382009en.pdf Accessed 28 ${ }^{\text {th }}$ October, 2018

[8] Aryn, B. (2015). "Nigeria's Military Quails When Faced With Boko Haram".< http://time.com/3702849/nigerias army-boko-haram> accessed 10 December, 2018.

[9] Avant, D. (2005). Market for Force: The Consequences of Privatising Security. Cambridge: Cambridge University Press.

[10] Brown, M. (1975). Strain of Violence: historical Studies of American Violence and Vigilantism. New York: Oxford University Press, p. 130.

[11] Caitriona, D. and Drury A. (2017). "Marginalisation, Insurgency and Civilian Insecurity: Boko Haram and the Lord's Resistance Army," Peacebuilding, p. 148.

[12] Chiles, N. (2013). After Rejecting Nigeria's Amnesty Offer: Boko Haram Continues to Kill. Atlanta Blackstar. Available [online] at: http://atlantablackstar.com/2013/04/23/after-rejectingnigerias-amnesty-offer-boko-haram-contin-ues-to-kill. Retrieved $23^{\text {rd }}$ November, 2018

[13] Chukwuma O. \&Ubong E. (2014). "Private Military Contractors, War Crimes and International Humantarian Law" ScientiaMilitaria, South African Journal of Military Studies Vol. No. 1.

[14] Coser, L. (1956). The Functions of Social Conflict. Glencoe III: The Free Press.

[15] Daniel, A. (2017). "National heroes or coming anarchy?Vigilant youth and the war on terror in Nigeria," Critical Studies on Terrorism, p. 9.

[16] Evgeni M. (2015). The Privatized Art of War-Private Military and Security Companies and State
Responsibilities for Their Unlawful Conduct in Conflict Areas, Cambrige: Intersentia.

[17] Falola, T. and Heaton M. (2014) A History of Nigeria. Cambridge University Press, 2014, 34.

[18] Fortna, V. (2009) Does Peacekeeping Work? Princeton: Princeton University Press.

[19] Francis, D. (1999). "Mercenary Intervention in Sierra Leone: Providing National Security or International Exploitation?", Third World Quarterly, Vol. 20.

[20] Global Terrorism Index. (2015). Retrieved from economics andpeace.org: p. 2.

[21] Higazi, A. (2015). Mobilization into and against Boko Haram in North-East Nigeria. In: K. Tall, M. E. Pommerolle, \& M. Cahen (Edp.).: Collective Mobilis ation in Africa: Contestations, Resistance, Revolt. Leiden and Boston: Brill, p. 339

[22] Ifediora, A. (2005). "Arresting Urban Cris is and Conflicts in Nigeria: The Case of Warri and Environs." Nigeria: The Challenges of Democracy and Development in the Twenty-First Century . Ed. Christopher O Orubu, Emman N. Mordi and A. Oritsegbemilfediora. Benin City: Ethiope Publishing Corporation.

[23] Jack, M. (nd) "Eeben Barlow Speaks Out (pt.1): PMC and Nigerian Strike Force Devastates Boko Haram. Available [online] at: https://www.sofrep.com Accessed 14 November, 2018.

[24] James, J. (2008). Private Sector, Public Wars: Contractor in Combat - Afghanistan, Iraq, and Future Conflicts. Westport, CT: Praeger Security International.

[25] Justin, D. (2016). "Boko Haram: Diverging Approaches to Fighting Insurgency".Journal of Politics and Democratization, 4.

[26] Kramer, D. (2007). Does History Repeat Itself? A Comparative Analysis of Private Security Companies. Wies baden. GWV FachverlageGmBH.

[27] Laura, D. (2010). "Military Lawyer, Private Contractors, and the Problem of International Law Compliance" International Law and Politics Vol. 42.

[28] Lesice, G. (1995). "Command Responsibility in International Humanitarian Law" Transnational Law \& Contemporary Problems p. 319.

[29] LokeBisberg, N. (2016). "Private Military Companies in Africa" ,[2016] (2)(2) Journal of World Development, 8 Available [online] at: http://www.academia.edu/30665153/Private Military Co mpanies in Africa the case of STTEP in Nigeria. Accessed 14 December 2018.

[30] Mamah, E. (2013). 'Human Rights Monitor Rais es Alarm over Activities of Civilian JTF', The Vanguard (Nigeria), Available [online] at: http://www.vanguardngr.com/2013/07/human-rightsmonitor-raises-alarm- over-activities-of-civilian-jtf/ Accessed 12th November, 2018 
[31] Mandel, R. (2001). "The Privatisation of Security", Armed Forces and Society, Vol 28, No 1, pp 129-151.

[32] Matfess, H. (2016). Boko Haram is Enslaving Women, Making them Join the War. news week.com.

[33] Mohammed I. (nd). Boko Haram: Inside Story of Hunters, Vigilante and Military Offences Against Insurgence" Available [online] at: https://www.leadership.ng Accessed 30 November, 2018.

[34] Obaditan, Y. (2003). Antidotes to Political Violence. Lagos: Kunmi Communications Ltd.

[35] O'Brien, K. (2000). "Private Military Companies and African Security 1990-98", in Musah, A and K Fayemi (eds), Mercenaries: An African Security Dilemma. London: Pluto Press.

[36] Odomovo, A. (2014). Insurgency, Counter-Insurgency And Human Rights Violations In NigeriaAvailable [online] at: https://revis taselectronicas.ujaen.es/index.php/TAHRJ/art icle/download/2126/1866.Accessed December 5, 2018.

[37] Ogundipe S. (2018). Boko Haram kills Nigerian Army commander, dozens of soldiers in fresh attack, Available [online] at: https://www.premiumtimesng.com/news/headlines/29668 5-boko-haram-kills-nigerian-army-commander-dozensof-soldiers-in-fresh-attack.htmla Accessed 29th November 2018.

[38] Oluwaseun, B. (2016) 'Civillian Joint Task Force' (CJTF)- A Community Security Option: A Comprehensive and Proactive Approach to CounterTerroris m'. Journal for Deradicalization, 124.

[39] Ortiz, C. (2010). Private Armed Forces and Global Security: A Guide to the Is sues. Praeger, Oxford.

[40] Oyewole, S. (2013) "Boko Haram and the Challenges of Nigeria's War on Terror"Defence and Security Analysis, 8Available [online] at: https://www.researchgate.net/.../263520916 Boko Haram and the challenges_of_Nige. Accessed 11 December, 2018.

[41] Reno, W. (1997). "African Weak States and Commercial Alliances", African Affairs, Vol 96, No 338.

[42] Rineheart, J. ( 2010). 'Counterterrorism and Counterinsurgency', Perspectives on Terrorism, 4(5). Available [online] at: http://www.terrorismanalysts.com/pt/index.php/pot/articl e/view/122/html Accessed $9^{\text {th }}$ November, 2018.

[43] Ruta, N. (2009). "From Bosnia to Baghdad: The Case for Regulating Private Military and Security Companies", 7 Available [online] at: https://jpia.princeton.edu/sites/jpia/files/2009-1.pdf. Accessed 11 December 2018.

[44] Shearer, D. (1998). Private Armies and Military Intervention. London: International Institute for Strategic Studies. Adelphi Paper 316.
[45] Singer, P. (2003). Corporate Warriors: The Rise of the Privatised Military Industry. Cornell University Press: London \& Ithaca.

[46] Singer, P. (2007). Can't Win With 'EM, Can't Go To War Without 'Em: Private Military Contractors and Counter-Insurgency. Derived from Brookings Report (Counterproductive paper).Armed Forces Journal.

[47] Smith, E. (2003). The New Condottieri and US Policy: The Privatization of Conflict and Its Implications. Available [online] at: http://www.carlisle.army.mil/us awc/parameters/ Articles/02winter/smith. Acces sed 29th November 2018.

[48] Solomon, H. (2012) "Counter Terrorism in Nigeria: Responding to Boko Haram" RUSI Journal, 8-9.

[49] Szabolcs, T. (2018). "Why Some Private Military and Security Company Succeed and others Fail in Taking Over Public Tasks"36 Available [online] at: http://studenttheses.cbs.dk/bitstream/handle/ $\begin{array}{llll}\text { n10417/4952/ szabolcstam\%C3\%A1s sasv\% } & \text { C3\% }\end{array}$ A 1ri.pdf?sequence $=1>$ accessed 20 November 2018.

[50] Thurston, A. (2016): The disease is unbelief': Boko Haram's religious and political worldview. The Brookings Project on US Relations with the Islamic World - Analys is Paper.Retrieved frombrookingp.edu: $p$. 5 .

[51] Tshepo, T. (nd)" Private Military And Security Companies Policy In Africa: Regional Policy Stasis as Agency In International Politics",69. Available online at: https://www.ajol.info/index.php/smsajms/ article/view File/151279/140856. Accessed 11 December, 2018.

[52] United Nations (1949). 'United Nations Universal Declaration of Human Rights 1948', viewed 27 November 2018, from http://www.supremecourt.ge/files/uploadfile/pdf/act3.pdf

[53] Wisdom, P. (2013). '185 Feared Killed in JTF, Boko Haram Clash in Borno', Daily Independent (Nigeria), viewed 9 July 2013, from http://www.dailyindependentnig.com/2013/04/185feared-killed-in-jtf-boko- haram-clash-in-borno/ 